\title{
Performance and meat quality of broilers fed different levels of alpha-tocopherol ${ }^{1}$
}

\section{Desempenho e qualidade de carne de frangos de corte alimentados com diferentes níveis de alfa-tocoferol}

\author{
Latóya de Sousa Bezerra2*; Roberta Gomes Marçal Vieira Vaz³; Mônica Calixto da \\ Silva4; Kênia Ferreira Rodrigues3; Luiz Fernando Teixeira Albino5; Hérica de Araujo \\ Costa2; Aleane Francisca Cordeiro Barbosa6; Mayara da Cruz Ribeiro6; \\ Jerry Kleube Felix Monteiro Junior ${ }^{7}$; Magna Ferreira de Oliveira ${ }^{7}$
}

\section{Highlights}

The $50 \%$ alpha-tocopherol level met the birds' needs.

The different levels of alpha-tocopherol did not influence the performance of broilers.

The amounts of alpha-tocopherol did not influence the meat quality of broilers.

\begin{abstract}
This study aimed to evaluate the performance and meat quality of broilers fed different levels of alphatocopherol. A total of 240 one-day-old Cobb $500^{\circledR}$ male broiler chicks were reared until day 7 of life, as recommended by the commercial line, and were fed at only $50 \%$ of the alpha-tocopherol requirement. At day 8 , the chicks were weighed, homogenized, and allotted in a completely randomized design with four treatments $(50,100,150$, and $200 \%$ alpha-tocopherol requirement) and six replicates of ten chickens per experimental unit. Several variables were evaluated: weight gain, feed intake, feed conversion, carcass yield and prime cuts (drumstick, thigh, and breast), edible viscera (heart, liver, gizzard), immune organs (cloacal bursa and spleen), intestine weight and length, abdominal fat, breast meat color (lightness, redness, and
\end{abstract}

1 Part of the first author's Master Thesis, Federal University of Tocantins, Araguaína, TO, Brazil.

2 PhD Students, Tropical Animal Science Graduate Program, Federal University of Tocantins, UFT, Araguaína, TO, Brazil. E-mail: latoyanina@hotmail.com; hericaaraujocosta@gmail.com

3 Doctored Teachers from the Department de Zootecnia, Escola de Medicina Veterinária e Zootecnia, Federal University of Tocantins, UFT, Araguaína, TO, Brazil. E-mail: betagmvvaz@yahoo.com.br; rodrigueskf@mail.uft.edu.br

4 Doctored Teacher from the Department de Zootecnia, Federal University of Amazonas, UFRA, Paragominas, PA, Brazil. E-mail: monicalixto_@hotmail.com

5 Doctored Teacher from the Department de Zootecnia, Escola de Medicina Veterinária e Zootecnia, Federal University of Viçosa, UFV, Viçosa, MG, Brazil. E-mail: lalbino@ufv.com

6 PhD in Tropical Animal Science, Federal University of Tocantins, UFT, Araguaína, TO, Brazil. E-mail: aleanebarbosa@ hotmail.com

7 Students of the Master's Course of the Post-Graduate Program in Tropical Animal Science, UFT, Araguaína, TO, Brazil. E-mail: jerryjunior00@hotmail.com; magnaferreira09@gmail.com

* Author for correspondence

Received: Oct. 30, 2020 - Approved: Feb. 11, 2021 
yellowness), $\mathrm{pH}$, cooking loss, and shear force of the breast meat. Dietary alpha-tocopherol levels did not influence broiler performance, carcass yield, and prime cuts at 42 days of age. The edible viscera, immune organs, the length of the small intestine, and the abdominal fat, as well as the meat color (lightness, redness, and yellowness), $\mathrm{pH}$, cooking loss, and shear force of the breast meat, were not influenced. However, the small intestine yield increased linearly with increasing levels of alpha-tocopherol. The dietary levels of alphatocopherol did not influence the performance and meat quality of broilers from 8 to 42 days of age.

Key words: Antioxidant. Micronutrient. Productive performance. Carcass yield. Vitamin E.

\section{Resumo}

Objetivou-se avaliar o desempenho e a qualidade de carne de frangos de corte alimentados com diferentes níveis de alfa-tocoferol. Foram utilizados 240 pintos de corte, machos, da linhagem Cobb $50{ }^{\circledR}{ }^{\circledR}$, de um dia de idade, criadas até o sétimo dia de vida, de acordo com a recomendação da linhagem e recebendo ração com apenas $50 \%$ da exigência de alfa-tocoferol. Aos oito dias, as aves foram pesadas, homogeneizadas e os tratamentos distribuídos em delineamento inteiramente casualizado, com quatro tratamentos $(50,100$, 150 e 200\% das exigências de alfa-tocoferol) e seis repetições de dez aves por unidade experimental. As variáveis avaliadas foram o ganho de peso, o consumo de ração, a conversão alimentar, os rendimentos de carcaça e cortes nobres (coxa, sobrecoxa e peito), as vísceras comestíveis (coração, fígado, moela), os órgãos imunes (Bolsa cloacal e Baço), peso e comprimento do intestino delgado, a gordura abdominal, a coloração (luminosidade, vermelho e amarelo), o pH, a perda de peso por cocção e a força de cisalhamento do músculo do peito. Observou-se que os níveis de alfa-tocoferol, não influenciaram as variáveis de desempenho das aves aos 42 dias de idade. Da mesma forma, não influenciaram o rendimento de carcaça e cortes nobres. As vísceras comestíveis, os órgãos imunes, o comprimento do intestino delgado e a gordura abdominal, também não foram influenciadas, assim como, a coloração (luminosidade, vermelho e amarelo), o pH, a perda de peso por cocção e a força de cisalhamento do músculo do peito. Porém, houve efeito linear crescente para o rendimento do intestino delgado. Os níveis de alfa-tocoferol nas dietas, não influenciaram o desempenho e a qualidade de carne de frangos de corte dos 8 aos 42 dias de idade.

Palavras-chave: Antioxidante. Desempenho produtivo. Micronutriente. Rendimento de carcaça. Vitamin E.

\section{Introduction}

Commercial diets for broilers are based on the combination of several ingredients, in quantities adequate to meet their nutritional requirements at different stages, with the objective of maximum performance and minimum cost. Among the various components used in the production of feed are micronutrients, including vitamins and minerals. Since broilers cannot synthesize all vitamins in sufficient quantities for the perfect functioning of the organism, these are supplemented in the diet (Félix, Maiorka, \& Sorbara, 2009).

Alpha-tocopherol, one of the fatsoluble vitamins, is essential for the health and development of different animal species; is important for the integrity of the organs, the reproductive system, nervous system, muscle, bone, skin, bone marrow and even blood; participates in antioxidative processes; and can improve the immune response and 
the productive performance of broilers raised under high temperatures. These benefits, which may be related to it being a functional nutrient, have aroused interest in its use in diets at quantities above the requirements of the birds (Galli et al., 2017; Kuttappan et al., 2012).

Vitamin $\mathrm{E}$ is the generic name given to eight tocopherol and tocotrienol compounds: alpha $(\alpha)$, beta $(\beta)$, gamma $(\gamma)$ and delta $(\delta)$ tocopherol or tocotrienol. All are considered natural antioxidants, found in variable fractions in oils, eggs, liver, wheat and some dark green vegetables (Dalólio, Albino, Lima, da Silva, \& Moreira, 2015). The main difference in the structures of these compounds is the number of side chain bonds, which result in changes in the activity of the vitamin. Alpha-tocopherol is the most abundant and biologically active form, with the highest antioxidant capacity, and is distributed throughout the plasma and in animal and plant tissues (Urso et al., 2015).

There are several benefits of vitamin E, among them, the ability to improve the production performance and the quality of broiler meat, considerably improving the oxidative quality of the meat when administered in quantities above the standard requirement. These benefits have aroused the interest of researchers seeking improvements in production and in the quality of the final product (Wu et al., 2012; Félix et al., 2009; Kuttappan et al., 2012).

In a study evaluating the effects of the dietary supplementation of ascorbic acid (115 and 230 ppm) and alpha-tocopherol (150 and 300 ppm) on broilers kept until 42 days of age in a high temperature environment, de Souza et al. (2011) noticed that although the combined vitamins positively influenced feed conversion and the breast yield of the birds, neither the single nor combined vitamins affected the performance, spleen weight, or blood parameters of the chickens. When combined with zinc (50 mg/kg feed), however, alpha-tocopherol (100 mg/kg feed) regulated the blood health indices and improved the performance of heat-stressed broilers (Hosseini-Mansoub, Chekani-Azar, Tehrani, Lotfi, \& Manesh, 2010). Conversely, according to Lopes et al. (2015), zinc (0 and $120 \mathrm{mg} / \mathrm{kg}$ diet) and alpha-tocopherol (0,300, and 600 $\mathrm{mg} / \mathrm{kg}$ diet) did not improve the feed intake, weight gain, production viability, or production efficiency index of broilers maintained for the first 21 days of life at high temperatures and reared on re-used litter.

Contrasting results were found by Kakhki, Bakhshalinejad, Hassanabadi and Ferket (2017), who evaluated the effect of three levels of alpha-tocopherol acetate $(0$, 150 and $300 \mathrm{mg} / \mathrm{kg}$ of food) and three levels of zinc $(0,60$ and $120 \mathrm{mg} / \mathrm{kg}$ of feed) on performance, meat quality and the amount of zinc, selenium and alpha-tocopherol in the breast and thigh muscle and liver of broilers. The authors noted that zinc and alphatocopherol acetate did not influence carcass performance or yield parameters; however, alpha-tocopherol and zinc supplementation increased alpha-tocopherol deposition in the liver, chest and thigh. They concluded that dietary supplementation of $300 \mathrm{mg} / \mathrm{kg}$ of alpha-tocopherol can improve nutritional content and stability to muscle oxidation without any adverse effect on the growth performance of broilers.

However, other studies have found that alpha-tocopherol improved broiler performance and the quality of broiler meat raised up to 38 days of age (Hashizawa, 
Kubota, Kadowaki, \& Fujimura, 2013), as well as sensory attributes in chickens raised up to 63 days of age (Zdanowska-Sąsiadek et al., 2016). Given the variation in alpha-tocopherol supplementation at levels above the needs of the birds examined so far, the objective of this study was to evaluate the performance and quality of chicken meat fed with different levels of alpha-tocopherol.

\section{Material and Methods}

Theexperimenttookplace in thePoultry Sector of the Faculty of Veterinary Medicine and Zootechnics of the Federal University of Tocantins, located in Araguaína, Brazil (latitude 07011'27"S, longitude 48'12'22"W and altitude $236 \mathrm{~m})$, from 30 March to May 11, 2018. It was carried out according to a protocol approved by the Ethics Committee on the Use of Animals at the Federal University of Tocantins (CEUAUFT) ( $\left.n^{\circ} 23.101 .004458 .2017-51\right)$.

A total of 240, one-day-old, male, Cobb 500 broilers, were raised to 7 days, according to lineage recommendations, and fed a diet containing only $50 \%$ of the alphatocopherol requirements (alpha-tocopherol). At 8 days of age, birds with an average weight of $187.3 \pm 14.47 \mathrm{~g}$ were randomly assigned to the four treatments $(50,100,150$, and $200 \%$ of the alpha-tocopherol requirements, as recommended by Rostagno et al., 2017) (Table 1) in a completely randomized experimental design, with six replicates of ten birds per experimental unit.

Table 1

Alpha-tocopherol levels in diets for broilers at different stages of breeding

\begin{tabular}{|ccccc|}
\hline \multirow{2}{*}{ Breeding stage } & \multicolumn{4}{c|}{ Treatment (Ul kg feed) } \\
\cline { 2 - 5 } & $50 \%$ & $100 \%^{a}$ & $150 \%$ & $200 \%$ \\
\hline 8-21 days & 22.9 & 45.8 & 68.7 & 91.6 \\
\hline $22-42$ days & 18.0 & 36.1 & 54.1 & 72.2
\end{tabular}

a Requirements recommended by Rostagno et al. (2017).

The composition of the diets was calculated considering the nutritional needs of the birds, based on the recommendations of Rostagno et al. (2017) from 1 to 7, 8 to 21 and 22 to 42 days of age (Table 2). The birds were housed in an experimental shed, managed according to the behavior of the birds, with concrete floors, side curtains and thermoacoustic tiles, and $242.0 \mathrm{~m}^{2}$ boxes, with tubular feeders and pendant drinkers. Feeders were filled, waterers were cleaned and refilled twice a day, allowing free access to water and food throughout the experimental period. 


\section{Table 2}

\section{Composition of the diets for broiler chickens in different breeding phases (days)}

\begin{tabular}{|c|c|c|c|}
\hline \multirow{3}{*}{ Ingredient } & \multicolumn{3}{|c|}{ Quantity (g kg) } \\
\hline & \multicolumn{3}{|c|}{ Breeding phase (days) } \\
\hline & 1 to 7 & 8 to 21 & 22 to 42 \\
\hline Corn (7.88\%) & 561.00 & 581.10 & 627.00 \\
\hline Soybean meal (45\%) & 370.90 & 344.40 & 305.90 \\
\hline Dicalcium phosphate & 19.00 & 16.70 & 11.70 \\
\hline Soy oil & 21.20 & 30.90 & 34.60 \\
\hline Limestone & 11.20 & 9.90 & 8.30 \\
\hline Common salt & 5.00 & 5.00 & 4.40 \\
\hline DL-Methionine & 3.80 & 3.80 & 2.40 \\
\hline L-Lysine & 3.10 & 3.30 & 2.00 \\
\hline L-Threonine & 1.30 & 1.50 & 0.50 \\
\hline Mineral supplement & 1.00 & 1.00 & 1.00 \\
\hline Vitamin supplement & 1.00 & 1.00 & 1.00 \\
\hline Choline chloride & 0.90 & 0.80 & 0.60 \\
\hline Salinomycin & 0.50 & 0.50 & 0.50 \\
\hline Butylated hydroxytoluene & 0.10 & 0.10 & 0.10 \\
\hline Total & 1000.00 & 1000.00 & 1000.00 \\
\hline \multicolumn{4}{|c|}{ Calculated nutritional composition } \\
\hline Metabolizable energy (kcal kg) & 2975 & 3050 & 3175 \\
\hline Crude protein (g kg) & 222.00 & 208.00 & 195.70 \\
\hline Calcium (g kg) & 9.70 & 8.80 & 6.90 \\
\hline Available phosphorus (g kg) & 4.60 & 4.20 & 3.30 \\
\hline Digestible lysine (g kg) & 13.00 & 12.50 & 10.70 \\
\hline Methionine + digestible cystine $(\mathrm{g} \mathrm{kg})$ & 9.60 & 9.30 & 7.90 \\
\hline Digestible methionine (g kg) & 6.50 & 6.50 & 5.00 \\
\hline Digestive threonine (g kg) & 8.60 & 8.30 & 7.00 \\
\hline Sodium (g kg) & 2.20 & 2.20 & 2.00 \\
\hline
\end{tabular}

a Recommendation and vitamin supplement composition per $\mathrm{kg}$ of diet formulated at the $100 \%$ level according to Rostagno et al. (2017)

${ }^{b}$ Mineral supplement (kg/t feed): Broiler: pre-initial, 1,25; initial, 1.10; growth I (22-35 days), 1.00. Supplementation composition (mg/kg feed) in the growth phase: copper, 10; iron, 50; iodine, 0.8; manganese, 65; selenium, 0.30; zinc, 60 ${ }^{c}$ Vitamin (Vit.) supplement (kg/t feed): Broiler: pre-initial, 1,25; initial, 1.10; growth I (22-35 days), 1.00. Vit. A, 8,000.00 IU; Vit. D, 1,600.00 IU; Vit. K, 1400 mg; Vit. B1, 1,200 mg; Vit. B2, 4,000 mg; nicotinic acid, 28.00 mg; pantothenic acid, 9,600 mg; Vit. B6, 1900 mg; Vit. B12, 10 mg; folic acid, 560 mg; biotin, 56 mg. 
Until day 14 of life, the birds were artificially heated using incandescent bulbs (60 W), which were installed inside all boxing. The adopted light program was continuous light (24 h light, natural + artificial). During the experimental period, the environmental conditions (air temperature, relative air humidity, and black globe temperature) inside the facilities were monitored and recorded every 30 min, using Onset HOBOware (version 3.4.1; Onset Computer Corp., Bourne, MA, USA) data loggers, placed in the middle of the boxing. The mean values obtained were converted into the black globe humidity index (BGHI) (Buffington et al., 1981). The mean values of the air temperature, maximum air temperature, and minimum air temperature inside the shed during the experimental period were $26.7,34.7$, and $19.7^{\circ} \mathrm{C}$, respectively, and the relative humidity was $88 \%$, equivalent to $\mathrm{BGHI}$ values of 77.1 and 77.9 , respectively, for the initial and final phases.

The variables evaluated included the feed intake; weight gain; feed conversion; carcass yield; yields of noble cuts (thigh, drumstick, and breast), edible viscera (heart, liver, gizzard), and immune organs (cloacal bursa and spleen); the weight and length of the small intestine; abdominal fat; color of the breast meat $\left(\mathrm{L}^{*}=\right.$ luminosity, $\mathrm{a}^{*}=$ redness, $\mathrm{b}^{*}$ = yellowness); $\mathrm{pH}$; temperature; weight loss by cooking; and shear force.

Birds and feed were weighed at the beginning and at the end of the experimental period to determine weight gain and feed intake. The feed intake was calculated considering the amount of feed supplied and the leftovers in the feeders. The feed conversion was defined as the ratio between the ingested feed intake and the weight gain of the birds during the experimental period.
At 42 days of age, two birds from each plot, with a body weight close to the average of the plot $( \pm 5 \%)$, were submitted to an 8 -h fast and slaughtered by cervical dislocation. Afterwards, they were submitted to bleeding, scalding, plucking, and evisceration procedures, in order to evaluate the weights of their whole carcasses (feet, neck, and head) and noble cuts (thigh, drumstick, and chest).

The edible viscera, immune organs, abdominal fat, and small intestine were collected during evisceration, cleaned, dried on paper towels, and weighed separately on a precision scale. From the gizzard, all the adhered fat, its contents, and the koilin membrane were removed. In addition to the weight, the length of the small intestine was measured from the beginning of the duodenum to the ileocecal junction. The relative weight of the plucked and eviscerated carcass was calculated in relation to fasting weight. The relative weights of the cuts, edible viscera, immune organs, and small intestine were measured in relation to the plucked and eviscerated carcass.

The $\mathrm{pH}$ value of the raw meat of the chicken breast (without bone, skin, ligaments, and fat) was measured, and its color (CIELAB system) was evaluated $\left(L^{*}, a^{*}, b^{*}\right)$ using $a$ colorimeter (Chroma meter ${ }^{\circledR}$ ). Readings were performed at three different points to obtain a mean value.

To determine the weight loss by thawing, the frozen breast fillets were weighed, placed in a refrigerator for $24 \mathrm{~h}$ for thawing, and then weighed again. To determine the weight loss by cooking, the previously weighed breasts were roasted in an electric oven at $170{ }^{\circ} \mathrm{C}$ until reaching an internal temperature of $40^{\circ} \mathrm{C}$, at which stage they were 
turned over and roasted until they reached an internal temperature of $70{ }^{\circ} \mathrm{C}$. The samples were placed on absorbent paper for cooling to a temperature of 20 to $25^{\circ} \mathrm{C}$. They were then weighed, and the weight loss after cooking was determined, followed by storage at $4{ }^{\circ} \mathrm{C}$ for $24 \mathrm{~h}$, according to a method adapted from Froning and Uijttenboogaart (1988).

To determine the shear force, samples of the cylindrical breast fillets $(1.27 \mathrm{~cm}$ in diameter) were placed with the fibers oriented perpendicular to the blades of the WarnerBratzler apparatus.

The data of the evaluated variables were submitted to the normality (Crámer-von Mises) and homoscedasticity (Levene) tests.
To check the adjustment of the equation, the results of the " $F$ " test for models, the " $t$ " test for the parameters ( $\beta 0, \beta 1$ and $\beta 2$ ) of the models, and the coefficient of determination $\left(\mathrm{R}^{2}=\mathrm{SS}\right.$ regression/ SS total) were considered significant at $p \leq 0.05$. The statistical analysis was performed using Sisvar software (Ferreira, 2011).

\section{Results and Discussion}

In the current study, the levels of alphatocopherol in the diets had no significant effect ( $p>0.05$ ) on the feed intake, weight gain, feed conversion, or body weight of broilers at 42 days of age (Table 3 ).

Table 3

Mean values of feed intake (FI), weight gain (WG), feed conversion (FC), and weight at 42 days (CP) of broilers from 8 to $\mathbf{4 2}$ days of age according to the alpha-tocopherol level

\begin{tabular}{|c|c|c|c|c|c|c|c|c|c|}
\hline \multirow{2}{*}{ Variable } & \multicolumn{4}{|c|}{ Alpha-tocopherol (\%) } & \multirow{2}{*}{ Mean } & \multicolumn{3}{|c|}{$\mathrm{P}$} & \multirow{2}{*}{$\begin{array}{l}\mathrm{CV}^{\mathrm{a}} \\
\text { (\%) }\end{array}$} \\
\hline & 50 & 100 & 150 & 200 & & LE & QE & LD & \\
\hline $\mathrm{Fl}^{\mathrm{b}}(\mathrm{g})$ & 5321.77 & 5212.33 & 5140.18 & 5165.55 & 5209.96 & 0.215 & 0.484 & 0.888 & 4.44 \\
\hline$W^{b}(g)$ & 3163.20 & 3193.83 & 3178.52 & 3198.78 & 3183.58 & 0.533 & 0.874 & 0.578 & 2.48 \\
\hline $\mathrm{FC}^{\mathrm{b}}(\mathrm{g} \mathrm{g})$ & 1.682 & 1.632 & 1.617 & 1.614 & 1.637 & 0.076 & 0.374 & 0.843 & 3.91 \\
\hline $\mathrm{CP}^{\mathrm{b}}(\mathrm{g})$ & 3349.45 & 3380.33 & 3363.35 & 3383.78 & 3369.23 & 0.563 & 0.875 & 0.566 & 2.38 \\
\hline
\end{tabular}

a Coefficient of variation (\%)

b $\hat{Y}=N S$

$L E$ linear effect, $Q E$ quadratic effect, $L D$ linearity deviation, $p$ probability of type I error at $5 \%$ using the $\mathrm{F}$-test.

The absence of effects on the productive performance of birds indicates that the lowest level of vitamin $\mathrm{E}$, i.e. $50 \%$ of the requirements, corresponding to 2.29 and 1.80 $\mathrm{g} / 100 \mathrm{~kg}$ (Table 1) for the initial and growth phases, respectively, met the nutritional requirements of broilers from 8 to 42 days of age.
A similar study, in which male broilers aged 21 to 39 days received alphatocopherol levels of 10,30,50, 75 and 100 $\mathrm{mg} / \mathrm{kg}$ of feed, without any effect on the production parameters, led to the conclusion that the lowest level of alpha-tocopherol supplementation $(10 \mathrm{mg} / \mathrm{kg})$ met the requirements of the birds in the initial and growth stages (Pompeu et al., 2015). 
Likewise, no impact on the performance and carcass composition of broilers from 21 to 49 days was found by Almeida, Pinto, Poloni, Ponsano, \& Garcia (2009), when up to $400 \mathrm{mg} / \mathrm{kg}$ alpha-tocopherol and linseed (flaxseed) oil (in substitution of soybean oil) were incorporated into the diet. However, the experimental rations used in their study also contained alpha-tocopherol associated with the use of flaxseed oil, whereas the present study sought to evaluate only the effects of alpha-tocopherol on the productive performance of birds.

The levels of alpha-tocopherol in the diets did not affect $(p>0.05)$ the carcass, thigh, drumstick, or breast yields, or the abdominal fat of broilers slaughtered at 42 days of age (Table 4).
Consistent with these results, Kuttappan et al. (2012) reported no effect of alpha-tocopherol levels of 15, 50, 100, 200, and $400 \mathrm{mg} / \mathrm{kg}$ feed on carcass yields, cuts, or striated breast development in broilers. Likewise, broilers fed diets with alphatocopherol (0 and $250 \mathrm{mg} / \mathrm{kg}$ ) and ascorbic acid $(0,150,300$, and $450 \mathrm{mg} / \mathrm{kg}$ ) showed no differences in their carcass and breast yield at up to 49 days of age (Fernandes, Sakamoto, Peiter, Gottardo, \& Tellini, 2013). Accordingly, the authors suggested that the use of ascorbic acid and alpha-tocopherol levels below the mean values used by the industry did not interfere with the productive performance of the birds (Fernandes et al., 2013).

\section{Table 4}

Mean values of carcass yield (RY), thigh carcass yield (TCY), drumstick carcass yield (DSCY), breast yield (BY), and abdominal fat (AF) in broilers slaughtered at $\mathbf{4 2}$ days of age, according to the alphatocopherol level

\begin{tabular}{|c|c|c|c|c|c|c|c|c|c|}
\hline \multirow{2}{*}{ Variable } & \multicolumn{4}{|c|}{ Alpha-tocopherol (\%) } & \multirow{2}{*}{ Mean } & \multicolumn{3}{|c|}{$p$-value } & \multirow{2}{*}{$\begin{array}{l}C V^{a} \\
(\%)\end{array}$} \\
\hline & 50 & 100 & 150 & 200 & & LE & QE & LD & \\
\hline $\mathrm{RY} Y^{\mathrm{b}}(\%)$ & 85.11 & 84.50 & 84.53 & 85.05 & 84.80 & 0.945 & 0.227 & 0.933 & 1.32 \\
\hline $\mathrm{TCY}$ (\%) & 10.21 & 9.96 & 9.96 & 9.89 & 10.01 & 0.401 & 0.719 & 0.770 & 6.04 \\
\hline $\mathrm{DSCY}^{\mathrm{b}}(\%)$ & 13.18 & 13.17 & 13.19 & 12.64 & 13.05 & 0.193 & 0.316 & 0.620 & 5.04 \\
\hline $\mathrm{BY}(\%)$ & 32.98 & 32.91 & 32.90 & 32.29 & 32.77 & 0.401 & 0.626 & 0.795 & 4.08 \\
\hline $\mathrm{AF}^{\mathrm{b}}(\%)$ & 1.63 & 1.64 & 1.61 & 1.54 & 1.60 & 0.636 & 0.799 & 0.994 & 21.17 \\
\hline
\end{tabular}

${ }^{a}$ Coefficient of variation (\%)

b $\hat{Y}=N S$

$L E$ linear effect, $Q E$ quadratic effect, $L D$ linearity deviation, $p$ probability of type I error at $5 \%$ using the F-test.

Divergent results were found by Zdanowska-Sąsiadek et al. (2016), who evaluated the effect of diets containing alphatocopherol (44 and $200 \mathrm{mg} / \mathrm{kg}$ feed) on the productive performance and meat quality of broilers up to 63 days of age and found that alpha-tocopherol supplementation of $200 \mathrm{mg} / \mathrm{kg}$ did not influence the productive performance, but increased the carcass yield. 
The levels of alpha-tocopherol in the diets did not affect $(p>0.05)$ the relative weights of the heart, gizzard, liver, spleen, or bursa. However, there was a linear effect $(p<0.05)$ on the small intestine yield of broiler chickens slaughtered at 42 days of age (Table 5).

\section{Table 5}

Relative weight of the edible viscera (heart, gizzard, and liver), immune organs (cloacal bursa and spleen), and abdominal fat, and weight and length of the small intestine $(\mathrm{m})$ of broilers at 42 days old according to the alpha-tocopherol level

\begin{tabular}{|c|c|c|c|c|c|c|c|c|c|}
\hline \multirow{2}{*}{ Variable } & \multicolumn{4}{|c|}{ Alpha-tocopherol (\%) } & \multirow{2}{*}{ Mean } & \multicolumn{3}{|c|}{$p$-value } & \multirow{2}{*}{$\begin{array}{l}C^{a} \\
(\%)\end{array}$} \\
\hline & 50 & 100 & 150 & 200 & & $\overline{L E}$ & QE & LD & \\
\hline Heart $^{\mathrm{b}}(\%)$ & 0.34 & 0.38 & 0.36 & 0.36 & 0.36 & 0.788 & 0.064 & 0.208 & 8.31 \\
\hline Gizzard $^{\mathrm{b}}(\%)$ & 1.10 & 1.01 & 1.02 & 1.03 & 1.04 & 0.337 & 0.230 & 0.598 & 9.82 \\
\hline Liver $^{\mathrm{b}}(\%)$ & 1.35 & 1.46 & 1.43 & 1.41 & 1.41 & 0.565 & 0.248 & 0.601 & 9.91 \\
\hline Spleen $\left.^{\mathrm{b}} \%\right)$ & 0.08 & 0.07 & 0.08 & 0.07 & 0.08 & 0.472 & 0.536 & 0.096 & 20.36 \\
\hline Bursab $\left.^{b} \%\right)$ & 0.18 & 0.18 & 0.18 & 0.19 & 0.18 & 0.399 & 0.635 & 0.943 & 13.98 \\
\hline Intestine weight ${ }^{c}(\%)$ & 1.57 & 1.72 & 1.79 & 1.76 & 1.71 & 0.043 & 0.222 & 0.952 & 9.57 \\
\hline Length of intestine ${ }^{b}(\mathrm{~m})$ & 1.91 & 1.92 & 1.90 & 1.92 & 1.91 & 0.941 & 0.985 & 0.726 & 5.77 \\
\hline
\end{tabular}

${ }^{a}$ Coefficient of variation (\%)

b $\hat{Y}=N S$

c Linear effect: ID $=1.548+0.00129$ NVE $\left(p=0.043 ; R^{2}=0.75\right)$ where NVE $=$ alpha-tocopherol level

$L E$ linear effect, $Q E$ quadratic effect, $L D$ linearity deviation, $p$ probability of type I error at $5 \%$ using the $\mathrm{F}$-test.

The linear increase in the relative weight of the small intestine can be attributed to the fact that the size of the metabolically active viscera is reduced when birds are raised in environments above the thermoneutral zone, in order to promote the loss of heat to the environment (Lopes et al., 2015). Lopes et al. (2015) found similar results, demonstrating a linear increase in absolute small intestine weight of broiler chickens fed increasing levels of alpha-tocopherol (300 and 600 mg/ $\mathrm{kg}$ ). The small intestine is of fundamental importance for the development of the birds since most of the nutrient absorption occurs in this organ. Thus, when the size of the organ is compromised, the absorption of the nutrients is impaired (Reis et al., 2016).

The levels of alpha-tocopherol in the diets did not influence $(p>0.05)$ the color $\left(L^{*}, a^{*}\right.$, $\left.b^{*}\right), \mathrm{pH}$, temperature, shear force, or weight loss by cooking of the breast muscle of chickens slaughtered at 42 days of age (Table 6). 
Table 5

Mean values of luminosity $\left(L^{*}\right)$, redness $\left(a^{*}\right)$, yellowness $\left(b^{*}\right), \mathrm{pH}$, temperature, shear force, and cooking weight loss cut at 42 days of age

\begin{tabular}{|c|c|c|c|c|c|c|c|c|c|}
\hline \multirow{2}{*}{ Variable } & \multicolumn{4}{|c|}{ Alpha-tocopherol (\%) } & \multirow{2}{*}{ Mean } & \multicolumn{3}{|c|}{$p$-value } & \multirow{2}{*}{$\begin{array}{l}\mathrm{CV}^{\mathrm{a}} \\
(\%)\end{array}$} \\
\hline & 50 & 100 & 150 & 200 & & LE & QE & LD & \\
\hline$L^{* \mathrm{~b}}$ & 61.57 & 60.25 & 61.61 & 60.66 & 61.02 & 0.608 & 0.750 & 0.071 & 2.36 \\
\hline$a^{* \mathrm{~b}}$ & 10.32 & 11.02 & 10.80 & 11.05 & 10.80 & 0.297 & 0.585 & 0.465 & 9.29 \\
\hline$b^{* \mathrm{~b}}$ & 11.00 & 11.49 & 10.77 & 11.12 & 11.10 & 0.893 & 0.908 & 0.415 & 13.42 \\
\hline $\mathrm{pH}^{\mathrm{b}}$ & 6.16 & 6.23 & 6.06 & 6.15 & 6.15 & 0.527 & 0.881 & 0.133 & 2.84 \\
\hline Temperatureb $\left({ }^{\circ} \mathrm{C}\right)$ & 12.90 & 16.03 & 11.51 & 16.37 & 14.20 & 0.359 & 0.543 & 0.013 & 24.18 \\
\hline Weight loss by cooking (\%) & 22.59 & 21.76 & 24.37 & 23.99 & 23.18 & 0.207 & 0.847 & 0.232 & 12.33 \\
\hline Shear force $\left(\mathrm{kgf} / \mathrm{cm}^{2}\right)$ & 1.20 & 1.21 & 1.24 & 1.42 & 1.27 & 0.066 & 0.333 & 0.721 & 15.88 \\
\hline
\end{tabular}

${ }^{a}$ Coefficient of variation (\%)

b $\hat{Y}=N S$

$L E$ linear effect, $Q E$ quadratic effect, $L D$ linearity deviation, $p$ probability of type I error at $5 \%$ using the F-test.

Hu et al. (2015) compared the effects of $\alpha$-tocopherol acetate and vitamin $\mathrm{E}$, micro encapsulated on the production performance and meat quality of broiler chickens and did not observe effects on the levels of luminosity $\left(L^{*}\right)$, red $\left(a^{*}\right)$, yellow $\left(b^{*}\right)$, in the loss of weight by cooking and in the shear strength of the breast of broilers raised until 42 days of age. Divergent results were found by Hashizawa et al. (2013), who evaluated the effect of vitamin E supplementation on the quality of breast meat from broilers raised under heat stress up to 38 days of age and observed an effect on red $(a *)$ levels.

In a similar study, Zdanowska-Sąsiadek et al. (2016) evaluated two levels of vitamin E (44 mg / kg of vitamin E, basal diet and 200 $\mathrm{mg} / \mathrm{kg}$ of vitamin E, experimental diet) and observed an effect for calorimetry, where the meat of the group that received the highest level of vitamin $E$, obtained a higher content of red and lower content of yellow, when compared to the control group, for weight loss by cooking, the lowest values were found in the meat of birds that received the level of $200 \mathrm{mg} / \mathrm{kg}$ of vitamin $\mathrm{E}$.

In general, it was observed that the levels of alpha-tocopherol used in the present study did not influence the performance parameters and meat quality of broilers slaughtered at 42 days of age, these results may be related to the amounts of alpha- tocopherol added to the diets, the levels used, were lower than those reported by Silva et al. (2011) who used levels of 75, 150, 225 and $300 \mathrm{mg} / \mathrm{kg}$ of alpha-tocopherol, Zaboli, Bilondi, \& Miri, (2013) level of $200 \mathrm{mg} / \mathrm{kg}$ of alpha-tocopherol and Zdanowska-Sąsiadek et al. (2016) with levels of 44 and $200 \mathrm{mg} / \mathrm{kg}$ of alpha-tocopherol in the diets, in which the results showed better parameters of performance and meat quality, when the birds were fed diets containing higher levels of alpha-tocopherol. 


\section{Conclusion}

Concludes the alpha-tocopherol levels examined did not influence the performance parameters and quality of broiler meat from 8 to 42 days of age.

\section{Acknowledgment}

We wish to acknowledge the Coordination for the Improvement of Higher Education Personnel - CAPES, for the scholarship grant, the Federal University of Tocantins - UFT, for the support and availability of the facilities, as well as Teacher Luiz Fernando Albino and the companies Bonasa Alimentos and GRANFORTE for the supply of raw materials for the experiments.

"The development of this research benefited from the UFT Institutional Productivity Research Program (PROPESQ / UFT)".

\section{References}

Almeida, A.P.S., Pinto, M. F., Poloni, L. B., Ponsano, E. H. G., \& Garcia, M., Neto. (2009). Efeito do consumo de óleo de linhaça e de vitamina E no desempenho e nas características de carcaças de frangos de corte. Arquivo Brasileiro de Medicina Veterinária e Zootecnia, 61(3), 698-705. doi: 10.1590/ S0102-09352009000300025

Buffington, D. E., Collazo-Arocho, A., Canton, G. H., Pitt, D., Thatcher, W. W., \& Collier, R. J. (1981). Black globe-humidity index (BGHI) as comfort equation for dairy cows. Transactions of the ASAE, 24(3), 711-714. doi: $10.13031 / 2013.34325$
Dalólio, F. S., Albino, L. F. T., Lima, H. J. D., Silva, J. N. da, \& Moreira, J. (2015). Heat stress and vitamin $\mathrm{E}$ in diets for broilers as a mitigating measure. Acta Scientiarum, 37(4), 419427. doi: $10.4025 /$ actascianimsci.v37i4. 27456

Félix, A. P., Maiorka, A., \& Sorbara, J. O. B. (2009). Níveis vitamínicos para frangos de corte. Ciência Rural, 39(2), 619-626. doi: 10.1590/S0103-84782008005000073

Fernandes, J. I. M., Sakamoto, M. I., Peiter, D. C., Gottardo, E. T., \& Tellini, C. (2013). Relação vitamina E:vitamina $C$ sobre a qualidade da carne de frangos submetidos ao estresse pré-abate. Arquivo Brasileiro de Medicina Veterinária e Zootecnia, 65(1), 294-300. doi: 10.1590/S0102-09352013 000100042

Ferreira, D. F. (2011). Sisvar: a computer statistical analysis system. Ciência e Agrotecnologia, 35(6), 1030-1042. doi: 10. 1590/S1413-70542011000600001

Froning, G. W., \& Uijttenboogaart, T. G. (1988). Effect of post-mortem electrical stimulation on color, texture, $\mathrm{pH}$, and cooking losses of hot and cold deboned chicken broiler breast meat. Poultry Science, 67(11), 1536-1544. doi: 10.3382/ ps.0671536

Galli, F., Azzi, A., Birringer, M., Cook-Mills, J. M., Eggersdorfer, M., Frank, J., \& Özer, N. K. (2017). Vitamin E: Emerging aspects and new directions. Free Radical Biology and Medicine, 102(1), 16-36. doi: 10.1016/j. freeradbiomed.2016.09.017

Hashizawa, Y., Kubota, M., Kadowaki, M., \& Fujimura, S. (2013). Effect of dietary vitamin $\mathrm{E}$ on broiler meat qualities, color, water-holding capacity and shear force 
value, under heat stress conditions. Animal Science Journal, 84(11), 732-736. doi: 10.1111/asj.12079

Hosseini-Mansoub, N., Chekani-Azar, S., Tehrani, A. A., Lotfi, A., \& Manesh, M. K. (2010). Influence of dietary vitamin $E$ and zinc on performance, oxidative stability and some blood measures of broiler chickens reared under heat stress $\left(35^{\circ} \mathrm{C}\right)$. Journal of Agrobiology, 27(2), 103-110. doi: 10.2478/s10146-009-0012-1

Hu, Z. P., Wang, T., Ahmad, H., Zhang, J. F., Zhang, L. L., \& Zhong, X. (2015). Effects of different formulations of $\alpha$-tocopherol acetate (vitamin E) on growth performance, meat quality and antioxidant capacity in broiler chickens. British Poultry Science, 56(6), 687-695. doi: 10.1080/00071668.2015.108 0814

Kakhki, R. A. M., Bakhshalinejad, R., Hassanabadi, A., \& Ferket, P. (2017). Effects of dietary organic zinc and $\alpha$-tocopheryl acetate supplements on growth performance, meat quality, tissues minerals, and $\alpha$-tocopherol deposition in broiler chickens. Poultry Science, 96(5), 1257-1267. doi: 10.3382/ps/pew386

Kuttappan, V. A., Goodgame, S. D., Bradley, C. D., Mauromoustakos, A., Hargis, B. M., Waldroup, P. W., \& Owens, C. M. (2012). Effect of different levels of dietary vitamin E (DL- $\alpha$-tocopherol acetate) on the occurrence of various degrees of white striping on broiler breast fillets. Poultry Science, 91(12), 3230-3235. doi: 10.3382/ ps.2012-02397

Lopes, J. C. O., Figueirêdo, A. V. de, Lopes, J. B., Lima, D. C. P., Ribeiro, M. N., \& Sousa Lima, V. B. de. (2015). Zinco e vitamina E em dietas para frangos de corte criados em estresse calórico. Revista Brasileira de Saúde e Produção Animal, 16(2), 350-364. doi: 10.1590/S1519-99402015000200010

Pompeu, M. A., Baião, N. C., Lara, L. J. C., Rocha, J. S. R., Cardeal, P. C., Baião, R. C.,... Cunha, C. E. (2015). Desempenho de frangos de corte alimentados com diferentes níveis de suplementação de vitamina E. Arquivo Brasileiro de Medicina Veterinária e Zootecnia, 67(2), 506-510. doi: 10. 1590/ 1678-6841

Reis, J. S., Dionello, N. J. L., Nunes, A. P., Lopes, D. C. N., Gotuzzo, A. G., Tyska, D. U., \& Rutz, F. (2016). Morfometria intestinal em codornas de corte alimentadas com treonina digestível. Arquivo Brasileiro de Medicina Veterinária e Zootecnia, 68(4), 983-990. doi: 10.1590/1678-4162-8776

Rostagno, H. S., Albino, L. F. T., Donzele, J. L., Gomes, P. C., Oliveira, R. F. de Lopes, D. C, \& Euclides, R.F. (2017). Tabelas brasileiras para aves e suínos composição de alimentos e exigências nutricionais. Viçosa, MG: UFV Imprensa Universitária.

Silva, I. C. M. da, Ribeiro, A. M. L., Canal, C. W., Vieira, M. M., Pinheiro, C. C., Gonçalves, T., Ledur, V.S. (2011). Effect of vitamin E levels on the cell-mediated immunity of broilers vaccinated against coccidiosis. Revista Brasileira de Ciência Avícola, 13(1), 53-56. doi: 10.1590/S1516-635X2011000100008

Souza, M. G. de, Oliveira, R. F. M. de, Donzele, J. L., Assis Maia, A. P. de, Balbino, E. M., \& Oliveira, W. P. de. (2011). Utilização das vitaminas $\mathrm{C}$ e em rações para frangos de corte mantidos em ambiente de alta temperatura. Revista Brasileira Zootecnia, 4O(10), 2192-2198. doi: 10.1590/S151635982011001000019 
Urso, U. R. A., Dahlke, F., Maiorka, A., Bueno, I. J. M., Schneider, A. F., Surek, D., \& Rocha, C. (2015). Vitamin E and selenium in broiler breeder diets: effect on live performance, hatching process, and chick quality. Poultry Science, 94(5), 976-983. doi: 10. 3382/ps/pev042

Zaboli, G. R., Bilondi, H. H., \& Miri, A. (2013). The effect of dietary antioxidant supplements on abdominal fat deposition in broilers. Life Science Journal, 10(2s), 328-333.
Zdanowska-Sąsiadek, Ż., Michalczuk, M., Damaziak, K., Niemiec, J., Polawska, E., Gozdowski, D., \& Różańska, E. (2016). Effect of vitamin $E$ supplementation on growth performance and chicken meat quality. European Poultry Science, 80(2), 1-14. doi: 10.1399/eps.2016.152

Wu, X., Liu, Y., Zhang, L., Li, F., Wang, F., Cao, L., \& Yao, J. (2012). Effect of natural vitamin $E$ level and duration of supplementation on growth performance, breast meat quality and oxidative stability of broilers. Journal of Animal and Veterinary Advances, 11(18), 3268-327. 
